\title{
FEATURES OF CONFLICT MANAGEMENT IN THE LABOR TEAM OF INDUSTRIAL ENTERPRISE
}

Formulation of the problem. The practice of entrepreneurship confirms that in the conditions of development of organizational structures a special place in any team is occupied by conflict. This is because conflict is an integral part of every business. Therefore, there is a need for in-depth study of modern patterns of formation of organizational conflicts, ways to eliminate them and combat their consequences.

At the same time, the most important result of effective conflict management at the enterprise will be the formation of a mechanism for early prevention of conflict situations and a mechanism for eliminating conflicts that have already arisen.

Analysis of recent research and publications. In recent years, the issue of resolving conflicts in collectives has begun to gain wider discussion. This issue has been studied by both domestic and foreign scientists, including L. Emelyanko, V. Petlyukh, L. Torgova, A. Grinenko, O. Vinoslavska, I. Kalinkina, L. Orban-Lembrik, N. Grishina, G. Prokopenko, S. Anthony, M. Johnson, J. Sinfield, E. Altman and others. They considered the causes of conflicts in different groups, depending on their temperament, character, lifestyle and other reasons. However, not enough attention was paid to highlighting ways to overcome them.

The purpose of the article is to study the nature of the emergence and development of ways to resolve the conflict situation in the workforce of an industrial enterprise.

Presentation of the main research material. Conflicts of interests, positions and opinions constantly arise in society. The inevitability of such contradictions is a manifestation of the law of unity and the struggle of opposites, one of the classical laws of development. Nowadays, people's living conditions change often and quickly, sometimes dramatically, and the words "stress" and "depression" are known to many since school. Usually, the conflict in the social and labor sphere is perceived as an abnormal phenomenon: failure to work, an obstacle to the realization of strategic goals. Negative perception is quite justified, because any conflict carries a charge of enormous destructive force: the process of normal functioning of the enterprise is disturbed, relationships between people are destroyed, often the task of resolving the conflict is accompanied by the dismissal of some employees. However, the absence of conflicts should be considered evidence of stagnation, stagnation [1].

Conflicts arise in the process of interaction, communication of people, because the interests, views are different, and therefore conflicts exist as long as humanity exists. However, the generally accepted theory of conflicts, which comprehensively explains their nature, impact on the development of the team, society does not yet exist, despite numerous studies on the origin, formation of conflicts and their management.

The beginning of modern conflict theory was laid by German, Austrian and American sociologists in the early twentieth century. The concept of conflict can be defined as the lack of agreement between the two or more parties, which may be individuals or a group of employees. Each party does its best to have its point of view accepted, and prevents the other party from doing so. There are other definitions of conflict.

Modern views are that even with effective management in organizations, some conflicts are not only possible but even desirable.

Of course, conflict is not always positive. In some cases, it can interfere with the needs of the individual and even achieve the goals of the organization. However, in many cases, the conflict helps to identify diversity of views, provides additional information, helps to identify alternative solutions to problems. Conflicts in the workforce can play both negative and positive functions. The main functions of conflicts in the labor collective of an industrial enterprise: 1) positive: relief of tension between the conflicting parties; obtaining new information about the opponent; cohesion of the organization's staff to counter external enemies; stimulating change and development; removal of the syndrome of obedience in subordinates; 2) negative: high emotional and material costs of participation in the conflict; dismissal of employees, reduction of discipline, deterioration of social and psychological climate in the team; attitude to defeated groups as enemies; excessive enthusiasm for the process of conflict interaction, which is detrimental to work; after the end of the conflict - reducing the degree of cooperation between some employees; difficult restoration of business relations [2, p. 182-184]. The role of conflict depends on how effectively it is managed. To manage the conflict, it is necessary to understand the causes of the conflict situation. 
Conflict situation is a different position of the parties on a particular occasion, the desire for opposite goals, the use of different means to achieve them, the conflict of interests, motives and so on.

Conflict situations are usually based on objective contradictions, but sometimes any reason or incident is enough - and a conflict can arise [2, p. 184-186].

Conflict management can be expressed in the settlement, completion, prevention, prevention, mitigation, suppression, postponement, and so on. In this case, the main methods of conflict management are:

rivalry - a way focused on power, on the assertion of their own position, ie when one meets their needs at the expense of another, or may mean "defending their rights", protection of their point of view; coordination the opposite of rivalry, when a person ignores his own needs to meet the needs of another, that is, in this case there is an element of self-sacrifice, generosity and mercy; bias (diplomatic) - diplomatic postponement of the issue until better times, uncertain way of managing the conflict; cooperation - the opposite of bias, involves attempts to reach a joint solution and may take the form of disagreements to clarify both points of view and resolve mutual problems; compromise - finding a mutually beneficial solution through a mutual desire to reconcile, reduce tensions and make concessions [3].

Typology is important for the correct understanding and interpretation of conflicts. To select an adequate method of influence and management of the relevant conflict, it is advisable to classify depending on the main features: the method of resolution; spheres of manifestation; direction of influence; degree of expressiveness; number of participants; impaired needs (Fig. 1).

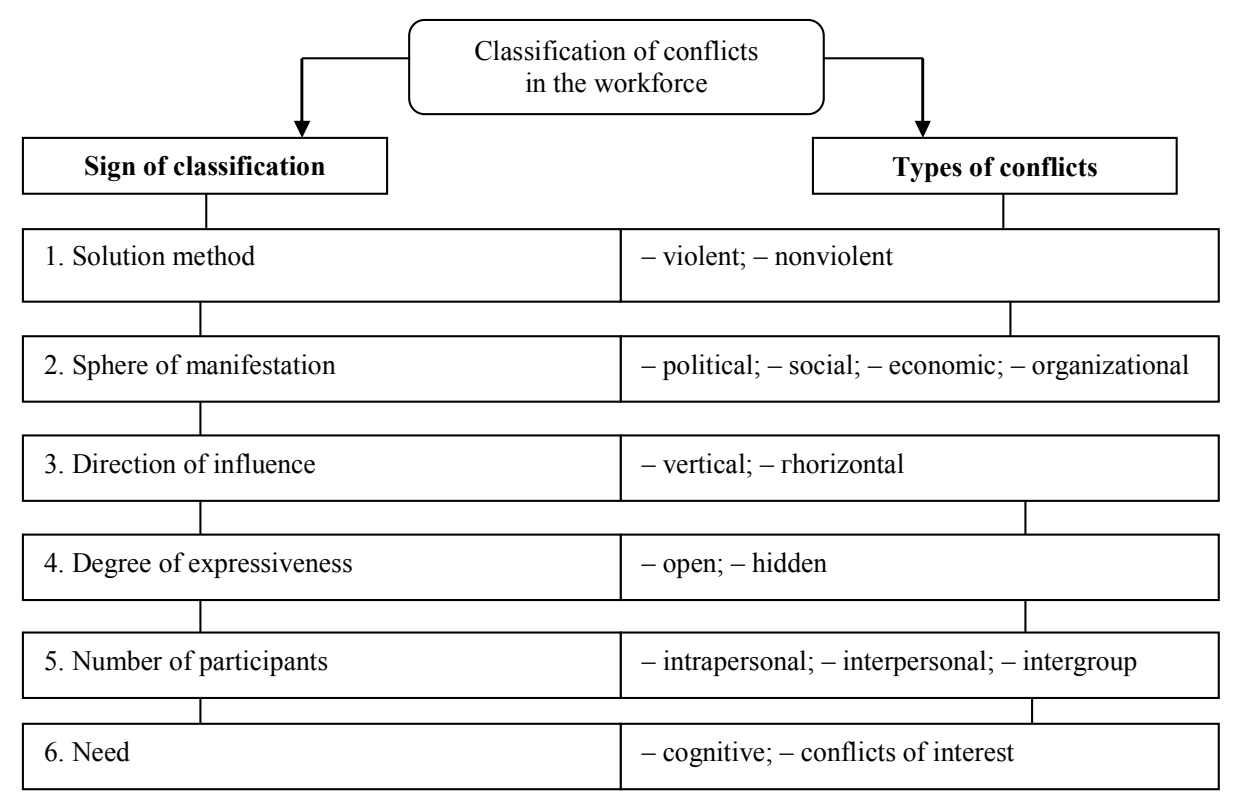

Fig. 1. Classification of conflicts in the labor collective of an industrial enterprise (formed by the author based on source [4])

In general, conflicts in the workforce can be divided into destructive and constructive. Manifestations of the destructive functions of conflict are very different. Personal conflict creates a state of psychological discomfort that causes other negative consequences and can lead to personality breakdown. At the group level, the conflict can destroy the system of communications, relationships, weaken the value-oriented unity of the group, reduce the effectiveness of its functioning as a whole. Similarly, the destructive functions of conflict manifest themselves in intergroup relationships [4].

The nature of interpersonal conflict in the organization of industrial production will be clearer if we consider the concept of the typology of creative personalities, created by S. Isaksen and K. Doravl in 1993. Scientists believe that creativity is inherent in all people to a greater or lesser extent, and different people's views on creativity differ depending on their propensity for creativity (Fig. 2).
We will note that the typical head of the industrial enterprise can be carried to adaptive-creative type of the person, the typical chief of department of the industrial enterprise - to innovative-creative, and the typical worker of department of the industrial enterprise - to type of innovators with low creativity. That is why there are various interpersonal conflicts and role conflicts [5]. The causes of conflicts can be classified as shown in Table 1.

Consider the destructive types of conflicts between employees of an industrial enterprise. Interpersonal conflict with personal differences according to S. Isaksen and K. Dorval usually arises between creative workers and accounts. If the views of the account and the creative worker do not coincide - the task of overcoming such a conflict passes to the manager of a higher level. Intergroup conflicts are primarily conflicts between the customer service department. Conflicts of roles within the organization begin to manifest themselves at the 
stage of acceptance of products developed by industrial enterprises.

It is clear that each manager tries to make certain corrections that can cause contradictions in colleagues, and, more often than not, will have no basis, but will reflect the peculiarities of his subjective taste. As a rule, all this does not have a positive effect on the end result, as there are several directors in the project who need to be pleased. And in the end, none of them will be satisfied. The conflict of desires is expressed in the fact that the customer sees the execution of the order so, and the executor, i.e. the industrial enterprise, quite differently.

Adaptive creative type

High level of creativity

Innovative creative type

\begin{tabular}{|c|c|c|}
\hline $\begin{array}{l}\text { - provides sufficient originality; } \\
\text { - inventive; } \\
\text { - effective; } \\
\text { - pedantic; } \\
\text { - has a special action plan; } \\
\text { - consistent }\end{array}$ & $\begin{array}{l}\text { - intellectual competence; } \\
\text { - openness to the new; } \\
\text { - energy and motivation; } \\
\text { - self-belief; } \\
\text { - professionalism in the field of its } \\
\text { activity }\end{array}$ & $\begin{array}{l}\text { - noticeable originality of thinking; } \\
\text { - has a developed intuition; } \\
\text { - resourceful; } \\
\text { - insightful; } \\
\text { - thinks spontaneously; } \\
\text { - informally }\end{array}$ \\
\hline $\begin{array}{l}\text { - submissively acknowledges his } \\
\text { submission; } \\
\text { - thinks categorically; } \\
\text { - inflexible; } \\
\text { - does not risk; } \\
\text { - compliant }\end{array}$ & $\begin{array}{l}\text { - mood of defeat; } \\
\text { - unwillingness to fight failures; } \\
\text { - emotional imbalance; } \\
\text { - feelings of anxiety; } \\
\text { - stubbornness }\end{array}$ & $\begin{array}{l}\text { - specific lines of action; } \\
\text { - thinks impractical; } \\
\text { - egocentric; } \\
\text { - sharp; } \\
\text { - unreliable; } \\
\text { - willing to take risks }\end{array}$ \\
\hline
\end{tabular}

Adepts

Low level of creativity

Innovators

with low creativity

Fig. 2. Typology of creative employees according to Isaksen and Dorval

(formed by the author based on source [4])

Causes of destructive conflicts in an industrial enterprise

Table 1

(formed by the author based on source [6])

\begin{tabular}{|l|l|l|}
\hline \multicolumn{1}{|c|}{$\begin{array}{c}\text { Common causes } \\
\text { of conflicts }\end{array}$} & \multicolumn{1}{|c|}{ concretization of the causes of different types of conflicts } \\
\cline { 2 - 3 } Conflict of roles & $\begin{array}{l}\text { Expectations of inadequate role actions (from } \\
\text { society, specific organization, management staff) }\end{array}$ & $\begin{array}{l}\text { Inadequate performance of social roles by partici- } \\
\text { and intergroup conflicts } \\
\text { pants in joint activities and management interaction } \\
\text { (different attitudes to activities, different goals of } \\
\text { activities) }\end{array}$ \\
\hline Conflict of desires & $\begin{array}{l}\text { Conflict of different desires (needs, interests, etc.) } \\
\text { in the mind of one person, which may be personal } \\
\text { or be related to the activities of the organization }\end{array}$ & $\begin{array}{l}\text { Conflict of consciousness of different people } \\
\text { (groups) concerning any desire, personal or con- } \\
\text { nected with the purposes of the organization (distri- } \\
\text { bution of limited resources, achievement of the pur- } \\
\text { pose in the course of competition) }\end{array}$ \\
\hline $\begin{array}{l}\text { Conflict of norms of } \\
\text { behavior }\end{array}$ & $\begin{array}{l}\text { Conflict of values, norms of behavior, life experi- } \\
\text { ence in the mind of one person }\end{array}$ & $\begin{array}{l}\text { Conflict of values, norms of behavior, life experi- } \\
\text { ence of people (groups) in the process of communi- } \\
\text { cation and social interaction }\end{array}$ \\
\hline
\end{tabular}

Such differences arise because industrial enterprises in their activities focus on research, market conditions, and the customer - on advertising competitors. The conflict of norms of behavior is also quite acute in working with industrial enterprises, because creative people often have other notions about rules and norms of behavior that are not accepted by customers.

To overcome destructive conflicts in the creative team, the manager must choose the most effective methods of overcoming such situations, depending on the nature and personal qualities of the participants in the creative process of the organization.

Conflict management can be expressed in the settlement, completion, prevention, prevention, weakening, suppression, postponement, etc. (Table 2) [7].
Constructive manifestations of the conflict are also diverse. It is known that personal conflict is not only able to negatively affect the personality, but can also contribute to positive development (for example, in the form of feelings of dissatisfaction with oneself). In group relations, conflict can prevent stagnation of the organization, be a factor in development, the emergence of new goals, norms, values. Conflict, especially at the stage of conflict behavior, plays a cognitive function, a function of practical verification and correction of those images of the situation.

By identifying the contradictions that exist between the members of the group and eliminating them at the stage of resolution, the conflict frees the team from destructive factors and contributes to its stabilization 
and sometimes further development. Thus, in the creative team of advertising agencies can generate new ideas, create plans for further creative development of the company and individuals [1].

Conflict management is purposeful, determined by objective laws influence on its dynamics in the interests of the development or destruction of the system to which the conflict relates.

Strategies for managing current conflicts. One of the most famous is the classification of approaches to conflict management, developed by K. Moore, which consists of six strategies: 1. Containment strategy - focused on the fact that the parties themselves can master the conflict. 2. Strategy of process support - focused on work with already established perception, relations, ways of interaction between the conflicting parties. 3. Socio-therapeutic support - focused on work at the individual level. 4. Mediation strategy - is used when the parties can no longer work together to resolve the conflict. 5. Arbitration Court - the "arbitrator" offers the parties a ready-made decision. 6 . Forceful intervention here the will of the participants is no longer taken into account, but the use of power, as a rule, is limited to the scope of differences [8].

Conflict management in the labor collective of an industrial enterprise can be represented by three types of models of such type as: 1) "win - win"; 2) "win - lose"; 3) "loss - loss".
At the same time, it is especially important to take into account the consequences of the conflict, which are usually considered from three positions, such as: 1) the substantive content of the conflict; 2) emotional component; 3) conflict resolution procedure.

The win-win model assumes that all three aspects of the consequences of the conflict are taken into account. In the event of a conflict, according to this model, the parties manage to make a mutually beneficial or mutually acceptable decision on the subject side of the conflict. The result of such a decision is also a lack of hostility between the parties and satisfaction with the procedures for resolving this conflict.

The "win-lose" model involves the satisfaction of only one of the parties (and even, as a rule, not completely). The losing side remains negative towards its opponent.

Failure to recognize the legitimacy of procedures that are a win-win for the other party gives rise to a new conflict.

The "loss - loss" model provides only a stop in the development of the conflict process, because in this situation there is no satisfaction on either side, which will provoke further development of the conflict.

Table 2 presents the methods of conflict management in the workforce of an industrial enterprise.

\section{Methods of conflict management in the workforce of an industrial enterprise} (formed by the author based on source [9])

\begin{tabular}{|c|c|}
\hline $\begin{array}{l}\text { Management } \\
\text { method }\end{array}$ & The essence of the method \\
\hline Completion & $\begin{array}{l}\text { Clarification of the requirements that the parties must comply with when overcoming the conflict. The pur- } \\
\text { pose of this work is for each employee to know clearly how the process should take place, who is in charge, } \\
\text { what results can be expected }\end{array}$ \\
\hline Prevention & $\begin{array}{l}\text { Formation in the team of public opinion about the conflicting parties. As you know, public opinion is a } \\
\text { strong regulator of people's behavior, many of which need constant approval and support. In conflict, they } \\
\text { may find themselves in isolation, which is unacceptable to them. Therefore, in order to maintain good rela- } \\
\text { tions in the team, they are often willing to give up confrontational behavior }\end{array}$ \\
\hline Prevention & $\begin{array}{l}\text { Coordination and integration of activities. Having a well-established hierarchy of powers in the organization } \\
\text { helps to organize the interaction of people, problem solving, decision-making, information flow. In order to } \\
\text { coordinate the work of units of the organization create intermediate services. Their purpose is to solve prob- } \\
\text { lem situations between two production units. Integration helps to combine the efforts of different subsystems } \\
\text { and substructures of the organization to achieve a common goal }\end{array}$ \\
\hline Attenuation & $\begin{array}{l}\text { Organization of co-production. To this end, the parties are entrusted with the task they are interested in } \\
\text { carrying out, but alone they cannot do so. } \\
\text { Appeal to the "arbitrator". This method can be effective if opponents agree to obey his decision. The most } \\
\text { authoritative person is often chosen as such a "judge". Often, very well, she is the head of the organization. }\end{array}$ \\
\hline Suppression & $\begin{array}{l}\text { Appeal to an intermediary. A person who decides to mediate in resolving the conflict should help each party } \\
\text { to see through the eyes of the opponent, in finding optimal ways to resolve it, generating new ideas, proposals } \\
\text { in the process of developing the final document, creating a business moral and psychological atmosphere in } \\
\text { solving the problem, monitoring the implementation of agreements, try to mitigate the process of over- } \\
\text { coming the conflict. } \\
\text { Application of administrative methods of conflict resolution. They can be justified when psychological and } \\
\text { other methods have proved ineffective. Most often, for this purpose they resort to structural changes in the } \\
\text { organization, removal from the organization of opponents, if their activities began to harm the team, to } \\
\text { change their status or belonging to another system, which would make it impossible to interact. }\end{array}$ \\
\hline Deferment & $\begin{array}{l}\text { Directing the efforts of all participants to achieve common goals. To do this, it is important to clearly, } \\
\text { unambiguously formulate the goal, anticipating the role and contribution of each party in achieving it. } \\
\text { Creating a reward system. Rewards (gratitude, award, promotion) are an effective means of influencing } \\
\text { people's behavior, including in a conflict situation. }\end{array}$ \\
\hline
\end{tabular}


Conflict resolution strategies can use a variety of technologies. Among them, the most commonly used are negotiation and mediation.

1. Negotiations between the parties to the conflict provide for the establishment of activities in the direction of settling disputes that have arisen between social actors on the basis of interdependence and divergence of interests. 2. Mediation involves the participation of a third party without interest. There are three types of mediation, such as formal (used in resolving labor disputes), informal and public (used by NGOs).

Mediation uses such strategies as: "agreement in principle" - there are many ways to decide the parties, taking into account the boundaries of the future agreement; "Formation of blocks" - involves solving the problem in stages.

Sometimes the negotiations create a kind of deadlock, when you have to apply several strategies to conclude a mutually beneficial agreement.

Forms of conflict resolution are: concession - one of the parties gives the prerogative to the other party; compromise or consensus - the parties try to resolve the conflict by making mutual concessions; care - the party does not cooperate with anyone to make a decision; cooperation - the search for the most acceptable solution for both parties [10].

Successful resolution of labor conflicts requires mastery of a set of tools, forms and methods of resolution, the ability to combine their varieties in accordance with real conditions. Under the resolution of labor conflict is understood the process of managerial influence on the course of labor conflict in order to remove the causes of its occurrence and negative consequences. This view does not deny the possibility of resolving the conflict in a natural way, because the "managerial" influence of factors on the course of the conflict in this case will be accidental. The resolution is not seen as some independent process over the labor conflict. This is actually the final stage of the conflict process.

It is carried out either through a change in the objective situation, or at the cost of psychological adjustment of the subjective image of the situation that has developed in the warring parties. Thus, the role of successful conflict management in the personnel management system is quite important, because a favorable psychological climate in the team is the key to concentrating on the main goal of the entity's existence - profit maximization.

Conclusions. In the conditions of market relations the important regulating factor of economic well-being of the enterprise becomes collective, and is more exact its working capacity and productivity. The internal conditions of the organization are quite variable, as they are influenced by many factors. All the variety of external influences finds its concentrated expression in the attitude of employees to the enterprise, so an important point is the formation of a favorable microclimate, in particular through the timely detection of conflict situations and prevention or resolution of conflict.
Diagnosis and management of organizational conflicts should be the key to the successful operation of the enterprise by creating a working atmosphere in the team, where everyone will feel comfortable and work to the maximum.

\section{Literature}

1. Олтман Э., Синфилд Дж., Джонсон М., Энтони С. Руководство инноватора: как выйти на новых потребителей за счет упрощения и удешевления продукта / пер. с англ. Москва: Альпина Паблишер, Юрайт, 2011. 346 с. 2. Крушельницька О. В., Мельничук Д. П. Управління персоналом: навч. посібник. Видання друге, перероб. й доп. Київ: «Кондор», 2005. 308 с. 3 . Сочинська-Сибірцева І. М. Роль креативних методів в системі управління конфліктними ситуаціями. Наукові праџзі КНТУ. Економічні науки. 2009. Вип. 15. С. 62-67. 4. Ємельянко Л. М. Конфліктологія: навч. посіб. / за заг. ред. В. М. Петлюха, Л. В.Торгової. Київ: КНЕУ, 2003. 315 с. 5. Управление конфликтами в организации рекламного производства. URL: http: //advlab.ru/. 6. Винославська О. В. Психологія: навч. посіб. Київ : ІНКОС, 2005. 386 с. 7. Креативное мышление в бизнесе / пер. с англ. Москва : Альпина Бизнес Букс, 2006. 228 с. 8. Голобородько Г. П., Щербак О. Г. Формування навичок діяльності 3 попередження та вирішення конфліктів у процесі професійної освіти майбутніх менеджерів. URL: http:// www.confcontact. com/Okt/32_Golob.htm. 9. ОрбанЛембрик Л. Е. Психологія управління : посібник. Київ: Академвидав, 2003. 255 с. 10. Криса О. Й. Природа конфліктів в організації // Тези доповідей V Міжнародної науково-практичної конференції «Маркетинг та логістика в системі менеджменту». Львів: Вид-во Нац. ун-ту «Львівська політехніка», 2004. 396 с. 11. Гітіс Т. П., Гітіс В. Б., Діденко Д. П. Дослідження рівня задоволеності працею персоналу промислових підприємств України. Економічний вісник Донбасу. 2018. № 2 (52). С. 206-211.

\section{References}

1. Altman E., Sinfield J., Johnson M., Anthony S. (2011). An Innovator's Guide: How to Reach New Customers by Simplifying and Reducing the Cost of a Product. Trans. from Engl. Moscow, Alpina Publisher, Yurayt [in Russian].

2. Krushelnytska O. V., Melnychuk D. P. (2005). Upravlinnia personalom: navch. posibnyk [Personnel management]. Second edition, revised. and ext. Kyiv, Condor [in Ukrainian].

3. Sochynska-Sybirtseva I. M. (2009). Rol kreatyvnykh metodiv $\mathrm{V}$ systemi upravlinnia konfliktnymy sytuatsiiamy [The role of creative methods in the system of conflict management]. Naukovi pratsi KNTU. Ekonomichni nauky - Scientific works of KNTU. Economic sciences, Issue 15, pp. 62-67 [in Ukrainian].

4. Yemelianko L. M. (2003). Konfliktolohiia [Conflictology]. Kyiv, KNEU. 315 p. [in Ukrainian].

5. Upravleniye konfliktami $\mathrm{v}$ organizatsii reklamnogo proizvodstva [Conflict management in the organiza- 
tion of advertising production]. (n.d.). Retrieved from http://advlab.ru/ [in Russian].

6. Vynoslavska O. V. (2005). Psykholohiia [Psychology]. Kyiv, INCOS. 386 p. [in Ukrainian].

7. Creative thinking in business. (2006). Trans. from Engl. Moscow, Alpina Business Books. 228 p. [in Russian].

8. Holoborodko H. P., Shcherbak O. H. Formuvannia navychok diialnosti $\mathrm{z}$ poperedzhennia ta vyrishennia konfliktiv $\mathrm{u}$ protsesi profesiinoi osvity maibutnikh menedzheriv [Formation of skills of activity on the prevention and the decision of conflicts in the course of professional education of future managers]. (n.d.). Retrieved from http://www.confcontact. com/Okt/32_Golob.htm [in Ukrainian].

9. Orban-Lembryk L. E. (2003). Psykholohiia upravlinnia [Management psychology]. Kyiv, Akademvydav. 255 p. [in Ukrainian].

10. Krysa O. Y. (2004). Pryroda konfliktiv v orhanizatsii [The nature of conflicts in the organization]. Marketynh ta lohistyka $v$ systemi menedzhmentu Marketing and logistics in the management system. Abstracts of the $\mathrm{V}$ International scientific-practical conference. Lviv, Nat. Lviv Polytechnic University. 396 p. [in Ukrainian].

11. Gitis T., Gitis V., Didenko D. (2018). Doslidzhennia rivnia zadovolenosti pratseiu personalu promyslovykh pidpryiemstv Ukrainy [Research of the level of satisfaction with the work of the personnel of industrial enterprises of Ukraine]. Ekonomichnyi visnyk Donbasu - Economic Herald of the Donbas, 2 (52), pp. 206-211 [in Ukrainian].

Ровенська В. В. Особливості управління конфліктними ситуаціями у трудовому колективі промислового підприємства

У статті проведено аналіз природи виникнення конфліктів та їхня класифікація. Представлено типологію креативних співробітників за Ісаксеном та Дорвалем. Виявлено, що конфлікт є важливою формою взаємодії між людьми і слугує засобом вирішення багатьох проблем. Доведено, що для вибору адекватного методу впливу й управління відповідним конфліктом доцільно проводити класифікацію залежно від основних ознак: спосіб вирішення; сфери прояву; спрямованості впливу; ступеня виразності; кількості учасників; порушених потреб. Визначено причини виникнення деструктивних конфліктів на промисловому підприємстві. Представлено методи управління конфліктами у трудовому колективі промислового підприємства, а також розглянуто основні технології регулювання конфлікту.
Ключові слова: конфлікти, трудовий колектив, управління конфліктами, причини виникнення конфліктів, технології регулювання конфлікту.

Rovenska V. Features of Conflict Management in the Labor Team of Industrial Enterprise

The article analyzes the nature of conflicts and their classification. The typology of creative employees according to Isaksen and Dorval is presented. It is revealed that the conflict is an important form of interaction between people and serves as a means of solving many problems. It is proved that for the choice of an adequate method of influence and management of the corresponding conflict it is expedient to carry out classification depending on the basic signs: a way of the decision; spheres of manifestation; direction of influence; degree of expressiveness; number of participants; impaired needs. The causes of destructive conflicts at the industrial enterprise are determined. Methods of conflict management in the labor collective of an industrial enterprise are presented, as well as the main technologies of conflict management are considered.

Keywords: conflicts, labor collective, conflict management, causes of conflicts, conflict management technologies.

Ровенская В. В. Особенности управления конфликтными ситуациями в трудовом коллективе промышленного предприятия

В статье проведен анализ природы возникновения конфликтов и их классификация. Представлена типология креативных сотрудников за Ісаксеном и Дорвалем. Выявлено, что конфликт является важной формой взаимодействия между людьми и служит средством решения многих проблем. Доказано, что для выбора адекватного метода влияния и управления соответствующим конфликтом целесообразно проводить классификацию в зависимости от основных признаков: способ решения; сферы проявления; направленности влияния; степени выразительности; количества участников; затронутых нужд. Определены причины возникновения деструктивных конфликтов на промышленном предприятии. Представлены методы управления конфликтами в трудовом коллективе промышленного предприятия, а также рассмотрены основные технологии регулирования конфликта.

Ключевые слова: конфликты, трудовой коллектив, управление конфликтами, причины возникновения конфликтов, технологии регулирования конфликта.

Received by the editors: 26.10 .2020 and final form 29.12.2020 